•研究报告・

\title{
青藏高原特有种子植物区系特征及 多样性分布格局
}

\author{
于海彬 ${ }^{1,2}$ 张镱锂 ${ }^{1,3^{*}}$ 刘林山 ${ }^{1}$ 陈 朝 ${ }^{4}$ 祁 威 ${ }^{1}$ \\ 1 (中国科学院地理科学与资源研究所, 陆地表层格局与模拟院重点实验室, 北京 100101) \\ 2 (中山大学生命科学学院, 广州 510275) \\ 3 (中国科学院大学, 北京 100049) \\ 4 (广东省生态环境技术研究所, 广州 510650)
}

\begin{abstract}
摘要: 青藏高原拥有丰富的种子植物, 但对该地区特有植物的区系特征以及多样性还鲜有报道。本文通过植物志 (书)以及在线数据库, 整理了只分布于青藏高原地区的种子植物名录及其地理分布, 分析了它们的科属特征、区系 成分以及多样性空间分布格局。结果表明: 青藏高原共有特有种子植物3,764种, 隶属113科519属, 多数为草本植 物 (76.3\%); 包含 100 种以上的科有菊科、毛茛科、列当科等 15 个, 属有马先蒿属(Pedicularis)、杜鹃花属 (Rhododendron)、紫堇属(Corydalis)等7个; 从属的区系成分来看, 温带成分占主导(67.5\%)。青藏高原特有植物多 样性格局呈现从高原东南部向西北部逐渐递减的趋势, 其中东喜马拉雅-横断山脉的物种多样性非常丰富, 而且 多数物种分布在高原的中海拔地带。理解青藏高原特有物种的特征及多样性格局对探讨高原植物区系的演化历史 和物种保护有重要启示。
\end{abstract}

关键词: 多样性格局; 植物区系; 特有现象; 高山植物; 青藏高原

\section{Floristic characteristics and diversity patterns of seed plants endemic to the Tibetan Plateau}

\author{
Haibin Yu ${ }^{1,2}$, Yili Zhang ${ }^{1,3^{*}}$, Linshan Liu ${ }^{1}$, Zhao Chen ${ }^{4}$, Wei Qi ${ }^{1}$ \\ 1 Key Laboratory of Land Surface Pattern and Simulation, Institute of Geographical Sciences and Natural Resources \\ Research, Chinese Academy of Sciences, Beijing 100101 \\ 2 School of Life Sciences, Sun Yat-sen University, Guangzhou 510275 \\ 3 University of Chinese Academy of Sciences, Beijing 100049 \\ 4 Guangdong Institute of Eco-environmental Science \& Technology, Guangzhou 510650
}

\begin{abstract}
The Tibetan Plateau (TP) harbors numerous seed plants, however, the floristic characteristics and diversity patterns of plants endemic to this region have been rarely studied. Based on several monographs and online databases, we compiled a list of seed plants that exclusively occur on the TP as well as their distribution at the county level. We further explored their characteristics, floristic composition and spatial distribution patterns. We identified 3,764 endemic seed plants belonging to 519 genera and 113 families, 76.3\% of which are herbaceous plants. Among them, 15 families (e.g. Asteraceae, Ranunculaceae, Orobanchaceae) and 7 genera (e.g. Pedicularis, Rhododendron, Corydalis) contain over 100 endemic species. Floristic composition analysis indicates that $67.5 \%$ of these endemic plants are temperate species. Species diversity declined gradually from the southeast to the northwest with hotspots located within the East Himalaya-Hengduan Mountains. Vertically, most species occurred at intermediate elevations. Understanding floristic characteristics and diversity patterns of Tibetan endemic flora shed light on future studies on the evolutional history and conservation practices in this area.
\end{abstract}

Key words: diversity patterns; flora; endemism; alpine plant; Tibetan Plateau

收稿日期: 2017-03-14; 接受日期: 2017-07-01

基金项目: 国家自然科学基金(41271068,41371120)、中国科学院陆地表层格局与模拟重点实验室开放基金(GJ-2017-03)和中国博士后科学基金 (2016M592568)

* 通讯作者 Author for correspondence. E-mail: zhangyl@igsnrr.ac.cn 
特有性是生物地理学研究的重要内容之一 (Kier et al, 2009)。对于局限分布于一定区域内的物 种来说, 它们的分布格局和多样性不仅与当前地 形、气候、土地利用等因素有关(Kreft \& Jetz, 2007; 陈圣宾等, 2011), 更与过去的地质变迁和气候波动 密切相关(Wiens \& Donoghue, 2004; Sandel et al, 2011; Feng et al, 2016)。因此, 了解一个地区特有种 的多样性格局, 对于认识该地区的植物区系特征、 起源、形成与演化具有十分重要的意义。此外, 特 有性已成为生物多样性保护研究关注的焦点, 为预 测生物多样性热点区域和确定优先保护区提供了 重要依据(Huang et al, 2016)。

了解一个地区物种的特有性首先要确定该地 区的特有种名录, 而特有种名录的确定取决于研究 区域的范围。因为物种的特有性与自然环境的紧密 相关性, 选取自然地理区域作为界定特有性的范围 较为合理。由于自然地理区域的边界很难界定, 人 们通常以行政边界(国界)来确定特有种(López et al, 2011), 虽然这对当地的生物多样性保护研究有指 导作用, 但是在一定程度上削弱了对植物区系形成 演化问题的认识。因此, 本研究使用的青藏高原边 界主要基于地形地貌因素, 拟从地理学的角度确定 青藏高原的范围(张镱锂等, 2002), 它主要包括青海 省和西藏自治区的全部以及四川省、云南省、甘肃 省和新疆自治区的部分地区。青藏高原范围的确定 为其特有种名录的确定提供了重要基础。

青藏高原地区拥有丰富的植物物种(吴玉虎, 2008; Zhang et al, 2016), 尤其是高原东南部的东喜 马拉雅和横断山脉地区, 不仅是全球生物多样性的 热点地区(Myers et al, 2000), 也是我国特有植物最 丰富的地区和高山植物区系的中心(吴征镒, 1998; Huang et al, 2016)。一直以来, 对青藏高原一些热点 地区(如三江源地区、横断山高山冰缘带、滇西北的 香格里拉) 的植物本底资料和区系特征不断有报道 (吴玉虎，1995，2000，2009; Xu et al, 2014; Zhu, 2015), 对青海西藏两省区维管植物的多样性格局 也有研究(Mao et al, 2013; Yan et al, 2013)。然而, 到 目前为止, 对整个青藏高原地区的特有种子植物特 征和多样性分布格局还鲜有报道。我们选取了与青 藏高原环境密切相关的特有种子植物作为研究对 象, 通过物种名录的确定和分布数据的收集, 初步 分析了青藏高原特有种子植物的特征和多样性格
局, 希望为青藏高原的生物地理学、谱系地理学和 生物多样性保护等研究提供参考。

\section{1 材料与方法}

\section{1 特有种子植物名录确定}

按照青藏高原边界, 我们收集只分布在青藏高 原地区的种子植物。主要依据专著《青藏高原维管 植物及其生态地理分布》(吴玉虎, 2008), 初步确定 青藏高原特有种子植物名录。因这部专著重点收录 的是青海和西藏两省区的植物, 我们再根据中国在 线植物志(http:// www.eflora.cn/) (只参考其中《中国 植物志》和Flora of China的物种名录), 以及四川、 云南和新疆3省区的植物志和《横断山区维管植物》 (中国科学院青藏高原综合科学考察队, 1993, 1994) 对名录进行补充。最后, 将收集到的物种名录上传 到The Plant List数据库(http://www.theplantlist.org/) 进行修订, 剔除无效或异名的物种。本文采用修订 的 APG III 分类系统对物种的科进行确定 (APG, 2009; 刘冰等, 2015)。

\section{2 物种统计和区系成分分析}

统计青藏高原特有种子植物的基本特征, 如 科、属、种数量及比例、植物的生长型和海拔范围 以及包含种数较多的科、属。依据吴征镒等(2006) 对种子植物科属分布区类型的划分系统, 对青藏高 原特有种子植物属的地理区系成分进行统计。

\section{3 多样性格局构建}

\subsection{1 物种分布数据收集}

基于县域尺度收集物种的分布数据。目前, 青 藏高原地区共覆盖209个县级行政区域(含市辖区; 附录1), 其中西藏自治区74 个, 青海省 42 个, 四川 省 45 个, 云南省 9 个, 甘肃省 26 个, 新疆自治区 13 个。物种的县级分布数据主要依据以下来源: (1)专 著, 如《青藏高原维管植物及其生态地理分布》 (吴 玉虎, 2008)和《中国特有种子植物的多样性及其地 理分布》(黄继红等, 2014); (2)在线数据库, 如中国 数字植物标本馆(CVH, http://www.cvh.org.cn/)和全 球生物多样性信息网络(GBIF, http://www.gbif.org/); (3)青藏高原野外调查数据; (4)文献资料(Zhang et al, 2016)。此外, 根据物种的县级分布情况, 统计每个物 种的植物区系分区。按照吴征镒等(2010)对中国植物 区系的划分, 青藏高原植物区系区包括8个地区 (region)和14个亚地区(subregion) (附录1)。 


\subsection{2 绘制物种分布图}

按照每个县和植物区系分区的物种数量, 在 ArcGIS 10.1 (ESRI)中绘制基于县域尺度和植物区 系区尺度的青藏高原特有种子植物多样性格局。根 据物种生长的海拔区间, 用 $\mathrm{R}$ 软件(R Core Team, 2016)统计青藏高原特有种子植物的垂直分布格局。

\section{2 结果}

\section{1 科属种统计}

青藏高原特有种子植物共有3,764种(不包含种
下分类单元，附录 2), 占中国特有种子植物的 24.9\%。按照修订的APG III分类系统, 它们隶属于 113科519属。其中草本植物2,873种, 灌木769种, 乔 木122种，分别占青藏高原特有种数的 $76.3 \% 、 20.4 \%$ 和3.3\%, 可见青藏高原特有种多数为草本植物。

从科的组成上看，青藏高原特有种子植物隶属 于 113 科，占中国种子植物科(258)的 $43.80 \%$ 。含 100 种以上的有菊科、毛茛科、列当科、杜鹃花科、报 春花科等15科(图1a), 共计2,634种, 占青藏高原特 有种数的 $69.98 \%$ 。
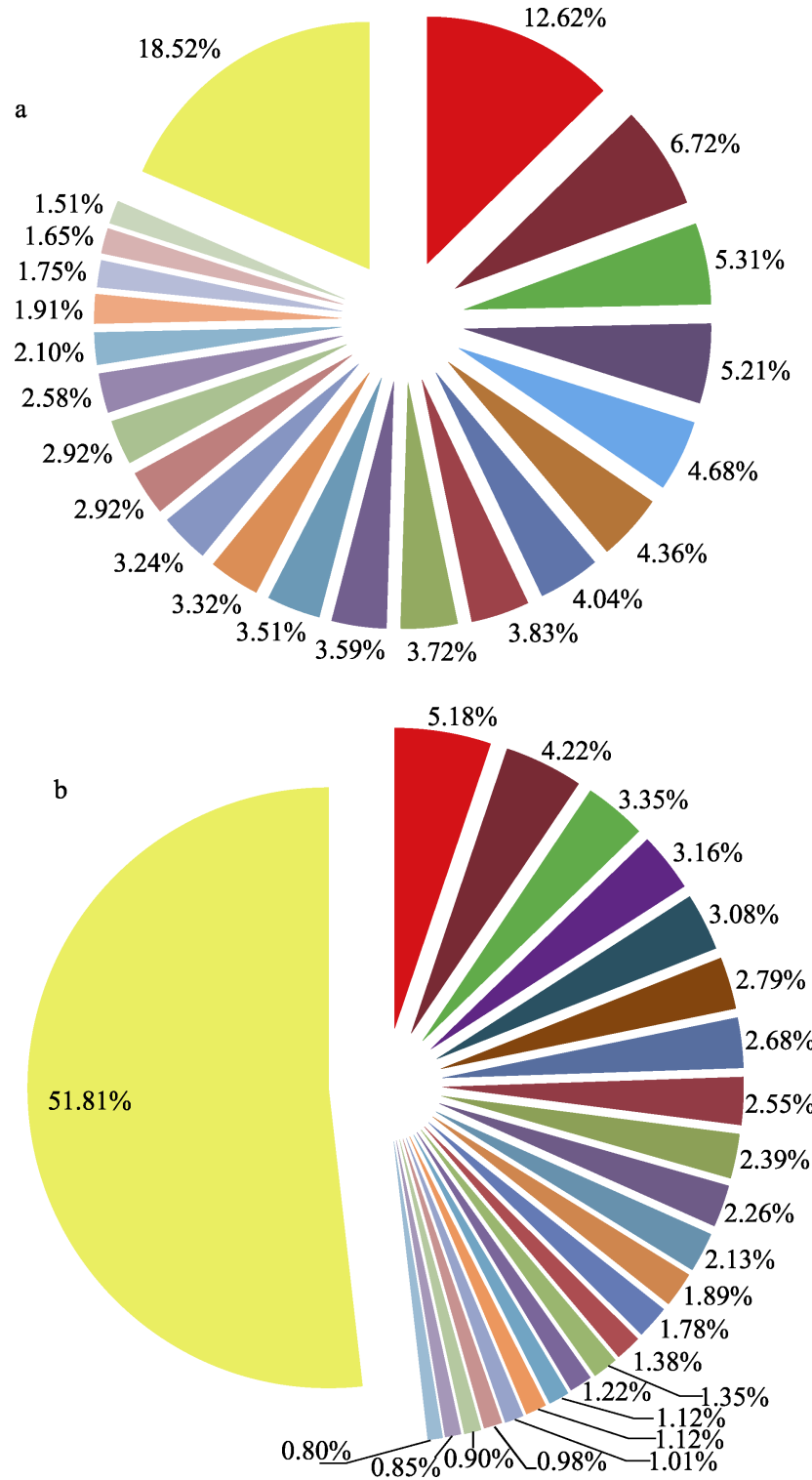

475 菊科 Asteraceae $\quad 125$ 石竹科 Caryophyllaceae

- 253 毛莨科 Ranunculaceae 122 虎耳草科 Saxifragaceae

- 200 列当科 Orobanchaceae 110 杨柳科 Salicaceae

- 196 杜鹃花科 Ericaceae 110 蓄微科 Rosaceae

-176 豆科 Fabaceae $\quad 97$ 小檗科 Berberidaceae

- 164 报春花科 Primulaceae -79 紫草科 Boraginaceae

- 152 唇形科 Lamiaceae $\quad 72$ 莎草科 Cyperaceae

- 144 罂粟科 Papaveraceae 66 兰科 Orchidaceae

140 企形科 Apiaceae 62 景天科 Crassulaceae

- 135 禾本科 Poaceae 57 十字花科 Brassicaceae

- 132 龙胆科 Gentianaceae 697 其他 Others

\section{- 195 马先蒿属 Pedicularis $\quad 67$ 无心菜属 Arenaria \\ - 159 杜鹃花属 Rhododendron -52 臺草属 Carex \\ -126紫堇属 Corydalis 51 䝴吾属 Ligularia \\ - 119 报春花属 Primula $\quad 46$ 景天属 Sedum \\ - 116 虎耳草属 Saxifraga $\quad 42$ 蒿属 Artemisia \\ - 105 风毛菊属 Saussurea』 42 蝇子草属 Silene \\ - 101 翠雀属 Delphinium $\quad 38$ 垂头菊属 Cremanthodium \\ - 96 柳属 Salix $\quad 37$ 凤仙花属 Impatiens \\ -90 小檗属 Berberis $\quad 34$ 香茶菜属 Isodon \\ - 85 龙胆属 Gentiana $\quad 32$ 箭竹属 Fargesia \\ - 80 黄芪属 Astragalus $\quad 30$ 紫茤属 Aster \\ - 71 乌头属 Aconitum 1950 其他 Others}

图 1 青藏高原含 50 个特有种以上科(a)和含 30 个特有种以上属(b)及其所占的比例。科属前面的数字代表它们包含的物种数。

Fig. 1 Percentages of families containing over 50 endemic species (a) and genera containing over 30 endemic species (b) on the Tibetan Plateau. The numbers before family or genus represent number of species they contain. 
从属的组成上看, 青藏高原特有种子植物隶属 于519属, 占中国种子植物属(2,872)的 $18.07 \%$ 。青藏 高原地区是一些特征属主要的分布和分化中心, 如 马先蒿属(Pedicularis), 该属包含中国特有种277种, 而只分布在青藏高原地区的就有195种(70.40\%); 虎耳草属(Saxifraga)含青藏高原特有种116种, 占该 属中国特有种的76.82\%; 翠雀属(Delphinium) 101 种, 占该属中国特有种的 $66.45 \%$ 。图1b为含 30 个特 有种以上的 23 个属所占的比例, 共包含物种 1,814 种, 占青藏高原特有种数的 $48.19 \%$, 其中马先蒿 属、杜鹃花属(Rhododendron)、紫堇属(Corydalis)、 报春花属(Primula)、虎耳草属、风毛菊属(Saussurea) 和翠雀属的物种数均超过 100 种。

\section{2 属的区系成分}

从属的区系成分来看, 青藏高原地区的主要区 系成分及比例分别为(表1): (1)世界分布属有40个, 占总属数的 $7.7 \%$; (2)热带分布属(第2-7类)有 129 个, 占总属数的 $24.8 \%$; (3)温带分布属(第8-15类)有 350 个, 占总属数的 $67.5 \%$, 可见温带成分占主导。

\section{3 多样性分布格局}

无论是基于县域尺度(图2a)还是植物区系区尺 度(图2b), 青藏高原地区特有种的多样性分布格局 都呈现出从东南部至西北部逐渐递减的趋势, 东喜 马拉雅和横断山脉地区是物种丰富度较高的区域。 从县级分布来看, 青藏高原特有种集中分布在滇西 北地区的德钦县、香格里拉县和丽江县、川西高原 中部和南部的康定县、木里县和稻城县以及藏东南 地区的察隅县、波密县、林芝县和墨脱县, 其中云 南省香格里拉县的特有种最多(924种)。此外, 青海 省东南部的玉树县和玛沈县以及西藏自治区南部 的错那县、亚东县、聂拉木县和吉隆县也具有相对 较多的特有种。从植物区系分区来看, 特有种最多 的区域位于南、北横断山脉亚地区、三江峡谷亚地 区和藏东南亚地区, 而西藏西北部的㒸塘高原、青 海省的柴达木盆地和新疆南部的西昆仑地区的特 有种很少, 这个区域大部分县包含的特有种不超过 10种。

从青藏高原特有种子植物的垂直分布格局来 看(图3), 多数物种分布在海拔3,000-4,000 $\mathrm{m}$ 的范 围内。多数草本植物生长在 $3,500 \mathrm{~m}$ 以上的高海拔地 区, 而灌木多生长在海拔 $3,000 \mathrm{~m}$ 左右, 多数乔木则 生长在海拔2,000-3,000 m的范围内。

\section{表1 青藏高原特有种子植物属的分布区类型}

Table 1 Areal types for the genera of seed plants endemic to the Tibetan Plateau

\begin{tabular}{|c|c|c|c|}
\hline & 分布类型 Areal type & 属数 Number of genera & 百分比 \% \\
\hline 1 & 世界分布 Cosmopolitan & 40 & 7.7 \\
\hline 2 & 泛热带 Pantropic & 45 & 8.7 \\
\hline 3 & 东亚及热带美洲间断 Tropical Asia and Tropical America disjunction & 9 & 1.7 \\
\hline 4 & 旧世界热带 Old World Tropic & 16 & 3.1 \\
\hline 5 & 热带亚洲至热带大洋洲 Tropical Asia to Tropical Australia & 15 & 2.9 \\
\hline 6 & 热带亚洲至热带非洲 Tropical Asia to Tropical Africa & 13 & 2.5 \\
\hline \multirow[t]{2}{*}{7} & 热带亚洲 Tropical Asia & 31 & 5.9 \\
\hline & 热带成分小计(2-7) Subtotal in tropical elements (types 2-7) & 129 & 24.8 \\
\hline 8 & 北温带 North Temperate & 131 & 25.2 \\
\hline 9 & 东亚及北美间断 East Asia and North America disjunction & 20 & 3.9 \\
\hline 10 & 旧世界温带 Old World Temperate & 50 & 9.7 \\
\hline 11 & 温带亚洲 Temperate Asia & 11 & 2.1 \\
\hline 12 & 地中海、西亚至中亚 Mediterranean, West Asia to Central Asia & 10 & 1.9 \\
\hline 13 & 中亚 Central Asia & 19 & 3.6 \\
\hline 14 & 东亚 East Asia & 65 & 12.6 \\
\hline \multirow[t]{3}{*}{15} & 中国特有 Endemic to China & 44 & 8.5 \\
\hline & 温带成分小计(8-15) Subtotal in temperate elements (types 8-15) & 350 & 67.5 \\
\hline & 总计 Total & 519 & 100.0 \\
\hline
\end{tabular}



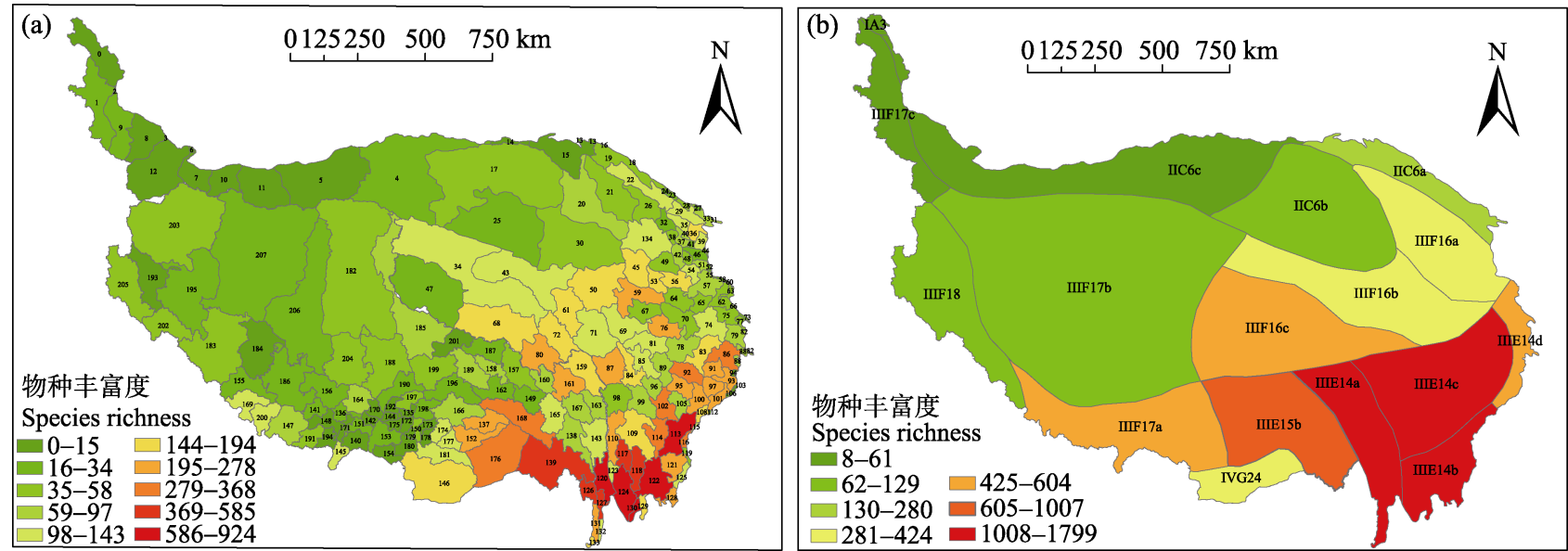

图2 基于县域尺度(a)和植物区系区尺度(b)的青藏高原特有种子植物多样性分布格局。图中编号对应附录1中的县级行政区 名称和植物区系区名称。

Fig. 2 Diversity patterns of endemic seed plants on the Tibetan Plateau at the county level (a) and floristic level (b). The codes correspond to the name of county and floristic region on the Tibetan Plateau in Appendix 1.
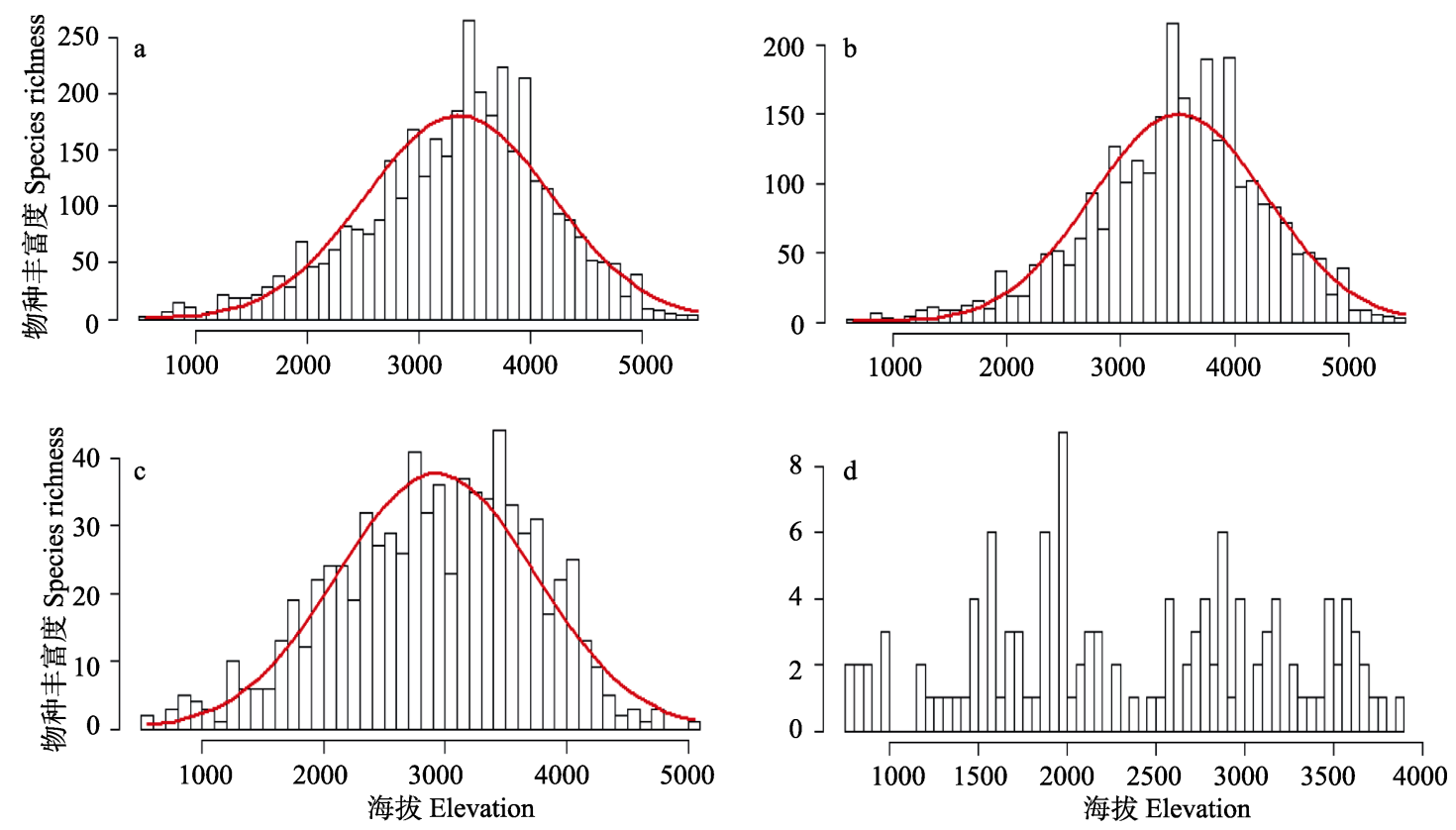

图3 垂直方向上不同生长型特有物种的丰富度格局。(a)所有物种; (b)草本; (c)灌木; (d)乔木。

Fig. 3 Species richness of different growth forms of endemic seed plants along elevational gradients. (a), All species; (b), Herb; (c), Shrub; (d), Tree.

\section{3 讨论}

目前, 对中国特有种子植物的特征已经有了较 深入的了解(Huang et al, 2011; 黄继红等, 2014), 这 为我们理解青藏高原特有种的特征提供了很好的 比较材料。与中国特有种的生长型所占比例相比(草 本占67.8\%), 青藏高原特有种中草本植物的比例更 高(76.3\%), 这与高海拔环境下较为适合草本植物
生存有关。一些大的属如马先蒿属、虎耳草属包含 较多的中国特有种(黄继红等, 2014), 其中大部分为 青藏高原特有种, 这可能与青藏高原地区是许多类 群的分布和分化中心有关(Gao et al, 2015; Yu WB et $\mathrm{al}, 2015)$ 。从属的分布区类型来看, 中国特有种子植 物属以热带成分居多(42.0\%), 而青藏高原则以温 带成分为主(67.5\%), 对三江源区、横断山高山冰缘 带和滇西北香格里拉植物区系的分析结果也得到 
温带成分为主的结论(吴玉虎, 1995, 2000, 2009; Xu et al, 2014; Zhu, 2015)。

本研究揭示的青藏高原特有种子植物的多样 性分布格局, 为探讨高原植物区系的形成演化提供 了重要启示。目前, 对生物多样性格局的形成原因 更多地从历史和进化的角度来探讨, 而地质活动和 过去的气候变化常被认为是改变生物多样性格局 的两大历史因素(Wiens \& Donoghue, 2004; Sandel et al, 2011)。在青藏高原地区, 来自历史生物地理研 究的一系列证据表明: 新近纪的高原快速隆升以及 第四纪的周期性气候波动促进了植物的辐射分化 和多样化(Qiu et al, 2011; Wen et al, 2014), 我们推 测这两大因素可能影响了青藏高原的植物分布格 局和多样性。

青藏高原自5,000万年前开始隆升, 尤其在中 新世至上新世时期(新近纪, 23-2.6 Ma), 青藏高原 经历了快速隆升阶段(施雅风等, 1998)。高原隆升不 仅改变了大气环流, 促进了亚洲季风气候的产生, 而且逐渐形成了高海拔特殊生境以及复杂的地形。 来自分子钟的证据表明: 高原上的很多物种都是这 个时期分化形成的，如报春花属(Ren et al, 2015)、 虎耳草属(Gao et al, 2015)、龙胆属(Gentiana) (Favre et al, 2016)和红景天属(Rhodiola) (Zhang et al, 2014) 等。这些属的分化不仅与高原快速隆升加速了本地 物种的适应性辐射有关, 也与复杂地形促进了物种 的隔离分化有关, 可见青藏高原一些大属的形成与 高原隆升密切相关。尤其是青藏高原东南部的东喜 马拉雅-横断山脉地区(温带成分为主), 一系列高大 山脉形成的地理障碍促进了物种的隔离分化和形 成, 解释了为什么该地区特有种多样性异常丰富以 及温带成分占主导的原因; 此外, 一些耐冷物种从 青藏高原向东亚、北美、中亚、欧洲、甚至北极的 高山或寒冷地区进行长距离迁移(如Matuszak et al, 2016)。因此, 该地区常被称为北温带植物的辐射地 以及全球生物多样性的热点地区 (吴征镒, 1998; Myers et al, 2000)。亚洲季风气候的形成, 造成了该 区域暖湿(高原东南部)到冷干(高原西北部)的气候 格局, 这种气候格局也深刻影响了青藏高原的物种 多样性格局(Mao et al, 2013; Yan et al, 2013)。

从物种垂直分布格局来看, 青藏高原多数植物 分布在中海拔地带(3,000-4,000 m), 对高黎贡山和
喜马拉雅山脉植物垂直分布格局的研究也有相似 的结论(Vetaas \& Grytnes, 2002; Wang et al, 2007), 这很可能是由于该海拔带的植物具有更多的时间 来积累和保存物种, 即Montane Museum假说, 该假 说不仅在龙胆属的多样化研究中得到验证(Favre et al, 2016), 而且普遍存在于华北植物区系的演变和 东亚植物的进化历史中 (Thorne, 1999; 王荷生, 1999)。另外一种可能就是中高海拔范围内的物种具 有更高的多样化率, 对19个科(属)的多样性研究发 现, 分布在横断山区物种的多样化率更高(Xing \& Ree, 2017)。

进入第四纪更新世时期(2.6-0.1 Ma), 周期性 的冰期进一步影响着物种分布(Svenning \& Skov, 2004)。尽管青藏高原没有形成像欧洲和北美大陆那 样的一块统一大冰盖, 但是最大一次冰期 $(0.72-$ $0.50 \mathrm{Ma})$ 还是迫使多数物种退缩至高原东部或东南 部的避难所内(Liu et al, 2014), 这也是造成高原东 南部物种多样性丰富的原因之一。另外, 在高原内 部还存在一些微型避难所, 如三江源地区(Yang et $\mathrm{al}, 2008)$, 使得这些地区的物种多样性也比较丰富。 此外, 冰后期一些物种发生了大范围的迁移扩散 (Cun \& Wang, 2010), 高原的一些山脉(喜马拉雅山) 或峡谷(雅鲁藏布江)地带可能充当了物种的迁移廊道 (Yu HB et al, 2015, 2017), 使得这些区域也拥有比较 丰富的物种。

总之, 高原隆升和气候波动深刻影响着青藏高 原特有种的多样性分布格局。在以后的研究中, 理 解当前植物区系的特征及物种多样性分布格局, 更 应从历史进化的角度来探讨过去环境变迁(如高原 隆升、气候波动等)与物种形成及多样化的关系。此 外, 由于本研究的数据主要来源于植物志书以及标 本馆的数据, 数据的滞后性和标本取样的不完全性 都会影响青藏高原植物多样性的估计(Yang et al, 2013), 在以后的研究中应不断跟进此地区的植物 调查数据。

致谢: 特别感谢中国科学院昆明植物研究所的杨永 平老师提供青藏高原维管植物名录, 中国林业科学 院森林生态环境与保护研究所的黄继红老师提供植 物区系分区矢量数据, 以及阿尔伯塔大学的毛岭峰博 士和中山大学的隋兴华博士提供部分物种分布数据。 


\section{参考文献}

APG (2009) An update of the Angiosperm Phylogeny Group classification for the orders and families of flowering plants: APG III. Botanical Journal of the Linnean Society, 161, 105-121.

Chen SB, Ouyang ZY, Fang Y, Li ZJ (2011) Geographic patterns of endemic seed plant genera diversity in China. Biodiversity Science, 19, 414-423. (in Chinese with English abstract) [陈圣宾, 欧阳志云, 方瑜, 李振基 (2011) 中国 种子植物特有属的地理分布格局. 生物多样性, 19, 414-423.]

Cun YZ, Wang XQ (2010) Plant recolonization in the Himalaya from the southeastern Qinghai-Tibetan Plateau: Geographical isolation contributed to high population differentiation. Molecular Phylogenetics and Evolution, 56, 972-982.

Favre A, Michalak I, Chen CH, Wang JC, Pringle JS, Matuszak S, Sun H, Yuan Y, Struwe L, Muellner-Riehl AN (2016) Out-of-Tibet: The spatio-temporal evolution of Gentiana (Gentianaceae). Journal of Biogeography, 43, 1967-1978.

Feng G, Mao LF, Sandel B, Swenson N, Svenning J (2016) High plant endemism in China is partially linked to reduced glacial-interglacial climate change. Journal of Biogeography, 43, 145-154.

Gao QB, Li YH, Gornall RJ, Zhang ZX, Zhang FQ, Xing R, Fu PC, Wang JL, Liu HR, Tian ZZ, Chen SL (2015) Phylogeny and speciation in Saxifraga sect. Ciliatae (Saxifragaceae): Evidence from $p s b A-t r n H$, trnL-F and ITS sequences. Taxon, 64, 703-713.

Huang JH, Chen JH, Ying JS, Ma KP (2011) Features and distribution patterns of Chinese endemic seed plant species. Journal of Systematics and Evolution, 49, 81-94.

Huang JH, Huang JH, Liu CR, Zhang JL, Lu XH, Ma KP (2016) Diversity hotspots and conservation gaps for the Chinese endemic seed flora. Biological Conservation, 198, 104-112.

Huang JH, Ma KP, Chen B (2014) Diversity and Geographical Distributions of Chinese Endemic Seed Plants. Higher Education Press, Beijing. (in Chinese) [黄继红, 马克平, 陈彬 (2014) 中国特有种子植物的多样性及其地理分布. 高等 教育出版社, 北京.]

Kier G, Kreft H, Lee TM, Jetz W, Ibisch PL, Nowicki C, Mutke J, Barthlott W (2009) A global assessment of endemism and species richness across island and mainland regions. Proceedings of the National Academy of Sciences, USA, 106, 9322-9327.

Kreft H, Jetz W (2007) Global patterns and determinants of vascular plant diversity. Proceedings of the National Academy of Sciences, USA, 104, 5925-5930.

Liu B, Ye JF, Liu S, Wang Y, Yang Y, Lai YJ, Zeng G, Lin QW (2015) Families and genera of Chinese angiosperms: A synoptic classification based on APG III. Biodiversity Science, 23, 225-231. (in Chinese with English abstract) [刘冰, 叶建飞, 刘夙, 汪远, 杨永, 赖阳均, 曾刚, 林秦文 (2015) 中国被子植物科属概览: 依据APG III系统. 生物 多样性, 23, 225-231.]

Liu JQ, Duan YW, Hao G, Ge XJ, Sun H (2014) Evolutionary history and underlying adaptation of alpine plants on the Qinghai-Tibet Plateau. Journal of Systematics and Evolu- tion, 52, 241-249.

López Pujol J, Zhang FM, Sun HQ, Ying TS, Ge S (2011) Centres of plant endemism in China: Places for survival or for speciation? Journal of Biogeography, 38, 1267-1280.

Mao LF, Chen SB, Zhang JL, Hou YH, Zhou GS, Zhang XS (2013) Vascular plant diversity on the roof of the world: Spatial patterns and environmental determinants. Journal of Systematics and Evolution, 51, 371-381.

Matuszak S, Muellner Riehl AN, Sun H, Favre A (2016) Dispersal routes between biodiversity hotspots in Asia: The case of the mountain genus Tripterospermum (Gentianinae, Gentianaceae) and its close relatives. Journal of Biogeography, 43, 580-590.

Myers N, Mittermeier RA, Mittermeier CG, da Fonseca GA, Kent J (2000) Biodiversity hotspots for conservation priorities. Nature, 403, 853-858.

Qiu YX, Fu CX, Comes HP (2011) Plant molecular phylogeography in China and adjacent regions: Tracing the genetic imprints of Quaternary climate and environmental change in the world's most diverse temperate flora. Molecular Phylogenetics and Evolution, 59, 225-244.

R Core Team (2016) R: A language and environment for statistical computing. R Foundation for Statistical Computing, Vienna. https://www.R-project.org/. (accessed on 2016-11-10)

Ren G, Conti E, Salamin N (2015) Phylogeny and biogeography of Primula sect. Armerina: Implications for plant evolution under climate change and the uplift of the QinghaiTibet Plateau. BMC Evolutionary Biology, 15, 161.

Sandel B, Arge L, Dalsgaard B, Davies RG, Gaston KJ, Sutherland WJ, Svenning J (2011) The influence of Late Quaternary climate-change velocity on species endemism. Science, 334, 660-664.

Shi YF, Li JJ, Li BY (1998) Uplift and Environmental Changes of Qinghai-Tibetan Plateau in the Late Cenozoic. Guangdong Science and Technology Press, Guangzhou. (in Chinese) [施雅风, 李吉均, 李炳元 (1998) 青藏高原晚新生 代隆升与环境变化. 广东科技出版社, 广州.]

Svenning J, Skov F (2004) Limited filling of the potential range in European tree species. Ecology Letters, 7, 565-573.

The Comprehensive Scientific Expedition to the Qinghai Xizang Plateau, Chinese Academy of Sciences (1993) Vascular Plants of the Hengduan Mountains, Vol. 1. Science Press, Beijing. (in Chinese) [中国科学院青藏高原综合科 学考察队 (1993) 横断山区维管植物(上册). 科学出版社, 北京.]

The Comprehensive Scientific Expedition to the Qinghai Xizang Plateau, Chinese Academy of Sciences (1994) Vascular Plants of the Hengduan Mountains, Vol. 2. Science Press, Beijing. (in Chinese) [中国科学院青藏高原综合科学考 察队 (1994) 横断山区维管植物(下册). 科学出版社, 北 京.]

Thorne RF (1999) Eastern Asia as a living museum for archaic angiosperms and other seed plants. Taiwania, 44, 413-422.

Vetaas OR, Grytnes JA (2002) Distribution of vascular plant species richness and endemic richness along the Himalayan elevation gradient in Nepal. Global Ecology and Biogeography, 11, 291-301.

Wang HS (1999) The evolution and sources of North China's flora. Acta Geographica Sinica, 54, 213-223. (in Chinese with English abstract) [王荷生 (1999) 华北植物区系的演 
变和来源. 地理学报, 54, 213-223.]

Wang ZH, Tang ZY, Fang JY (2007) Altitudinal patterns of seed plant richness in the Gaoligong Mountains, south-east Tibet, China. Diversity and Distributions, 13, 845-854.

Wen J, Zhang JQ, Nie ZL, Zhong Y, Sun H (2014) Evolutionary diversifications of plants on the Qinghai-Tibetan Plateau. Frontiers in Genetics, 5, 4.

Wiens JJ, Donoghue MJ (2004) Historical biogeography, ecology and species richness. Trends in Ecology and Evolution, 19, 639-644.

Wu YH (1995) The floristic characteristics in the source area of the Yellow River in China. Acta Botanica BorealiOccidentalia Sinica, 15, 82-89. (in Chinese with English abstract) [吴玉虎 (1995) 黄河源头地区植物的区系特征. 西北植物学报, 15, 82-89.]

Wu YH (2000) The floristic characteristics in the source area of Changjiang (Yangtze) River. Acta Botanica BorealiOccidentalia Sinica, 20, 1086-1101. (in Chinese with English abstract) [吴玉虎 (2000) 长江源区植物区系特征. 西 北植物学报, 20, 1086-1101.]

Wu YH (2008) The Vascular Plants and Their Eco-geographical Distribution of the Qinghai-Tibetan Plateau. Science Press, Beijing. (in Chinese) [吴玉虎 (2008) 青藏高原维管 植物及其生态地理分布. 科学出版社, 北京.]

Wu YH (2009) Floristic study on the source area of Lancangjiang (Mekong River), China. Journal of Wuhan Botanical Research, 27, 277-289. (in Chinese with English abstract) [吴玉虎 (2009) 澜沧江源区种子植物区系研究. 武汉植 物学研究, 27, 277-289.]

Wu ZY (1998) Flora of Tibet. Science Press, Beijing. (in Chinese) [吴征镒 (1998) 西藏植物志. 科学出版社, 北京.]

Wu ZY, Sun H, Zhou ZK, Li DZ, Peng H (2010) Floristics of Seed Plants from China. Science Press, Beijing. (in Chinese) [吴征镒, 孙航, 周浙昆, 李德铢, 彭华 (2010) 中国种子 植物区系地理. 科学出版社, 北京.]

Wu ZY, Zhou ZK, Sun H, Li DZ, Peng H (2006) The Arealtypes of Seed Plants and Their Origin and Differentiation. Yunnan Science and Technology Press, Kunming. (in Chinese) [吴征镒, 周浙昆, 孙航, 李德铢, 彭华 (2006) 种子 植物分布区类型及其起源和分化. 云南科技出版社, 昆明.]

Xing YW, Ree RH (2017) Uplift-driven diversification in the Hengduan Mountains, a temperate biodiversity hotspot. Proceedings of the National Academy of Sciences, USA, 114, 3444-3451.

Xu B, Li ZM, Sun H (2014) Plant diversity and floristic characters of the alpine subnival belt flora in the Hengduan
Mountains, SW China. Journal of Systematics and Evolution, 52, 271-279.

Yan YJ, Yang X, Tang ZY (2013) Patterns of species diversity and phylogenetic structure of vascular plants on the QinghaiTibetan Plateau. Ecology and Evolution, 3, 4584-4595.

Yang FS, Li YF, Ding X, Wang XQ (2008) Extensive population expansion of Pedicularis longiflora (Orobanchaceae) on the Qinghai-Tibetan Plateau and its correlation with the Quaternary climate change. Molecular Ecology, 17, 5135-5145.

Yang WJ, Ma KP, Kreft H (2013) Geographical sampling bias in a large distributional database and its effects on species richness-environment models. Journal of Biogeography, 40, 1415-1426.

Yu HB, Zhang YL, Liu LS, Qi W, Li SC, Hu ZJ (2015) Combining the least cost path method with population genetic data and species distribution models to identify landscape connectivity during the Late Quaternary in Himalayan hemlock. Ecology and Evolution, 5, 5781-5791.

Yu HB, Zhang YL, Wang ZF, Liu LS, Chen Z, Qi W (2017) Diverse range dynamics and routes of plants on the Tibetan Plateau during the Late Quaternary. PLoS ONE, 12, e0177101.

Yu WB, Liu ML, Wang H, Mill RR, Lee RH, Yang JB, Li DZ (2015) Towards a comprehensive phylogeny of the large temperate genus Pedicularis (Orobanchaceae), with an emphasis on species from the Himalaya-Hengduan Mountains. BMC Plant Biology, 15, 176.

Zhang DC, Ye JX, Sun H (2016) Quantitative approaches to identify floristic units and centres of species endemism in the Qinghai-Tibetan Plateau, south-western China. Journal of Biogeography, 43, 2465-2476.

Zhang JQ, Meng SY, Allen GA, Wen J, Rao GY (2014) Rapid radiation and dispersal out of the Qinghai-Tibetan Plateau of an alpine plant lineage Rhodiola (Crassulaceae). Molecular Phylogenetics and Evolution, 77, 147-158.

Zhang YL, Li BY, Zheng D (2002) A discussion on the boundary and area of the Tibetan Plateau in China. Geographical Research, 21, 1-8. (in Chinese with English abstract) [张镱 锂, 李炳元, 郑度 (2002) 论青藏高原范围与面积. 地理 研究, 21, 1-8.]

Zhu H (2015) Biogeography of Shangri-la flora in southwestern China. Phytotaxa, 203, 231-244.

(责任编委：陈圣宾 责任编辑: 黄祥忠)

\section{附录 Supplementary Material}

\section{附录1 青藏高原包含的县和植物区系区}

Appendix 1 Counties and floristic regions of the Tibetan Plateau http://www.biodiversity-science.net/fileup/PDF/2017078-1.xls

\section{附录2 青藏高原特有种子植物名录}

Appendix 2 Species list of endemic seed plants on the Tibetan Plateau http://www.biodiversity-science.net/fileup/PDF/2017078-2.xls 